\title{
Antibiotic-Induced Pathobiont Dissemination Accelerates Mortality in Severe Experimental Pancreatitis
}

\author{
Fernanda S. Soares ${ }^{1}$, Flávia C. Amaral', Natália L. C. Silva ${ }^{1}$, Matheus R. Valente', \\ Lorena K. R. Santos', Lívia H. Yamashiro', Mara C. Scheffer', Fernanda V. E. S. \\ Castanheira $^{3}$, Raphael G. Ferreira ${ }^{3}$, Laura Gehrke ${ }^{1}$, José C. Alves-Filho ${ }^{3}$, \\ Luciano P. Silva ${ }^{4,5}$, André Báfica ${ }^{1,6}$ and Fernando Spiller ${ }^{1,7 *}$
}

\begin{abstract}
'Laboratory of Immunobiology, Federal University of Santa Catarina (UFSC), Florianópolis, Brazil, ${ }^{2}$ Microbiology Laboratory, University Hospital, Federal University of Santa Catarina (UFSC), Florianópolis, Brazil, ${ }^{3}$ Department of Pharmacology, Ribeirao Preto Medical School, University of Sao Paulo, Ribeirao Preto, Brazil, ${ }^{4}$ Embrapa Genetic Resources and Biotechnology, Brasilia, Brazil, ${ }^{5}$ Institute of Biological Sciences, University of Brasilia, Brasilia, Brazil, ${ }^{6}$ Department of Microbiology, Immunology and Parasitology, Federal University of Santa Catarina (UFSC), Florianópolis, Brazil,

${ }^{7}$ Department of Pharmacology, Federal University of Santa Catarina (UFSC), Florianópolis, Brazil
\end{abstract}

OPEN ACCESS

Edited by:

Céline Cougoule,

Centre national de la recherche scientifique (CNRS), France

Reviewed by:

Juerg Hamacher,

Lindenhof Hospital

Ka Man Law,

University of California,

Los Angeles, United States

*Correspondence:

Fernando Spiller

fernando.spiller@ufsc.br

Specialty section:

This article was submitted to Inflammation,

a section of the journal

Frontiers in Immunology

Received: 29 June 2017 Accepted: 11 December 2017 Published: 22 December 2017

Citation:

Soares FS, Amaral FC, Silva NLC, Valente MR, Santos $L K R$, Yamashiro $L H$, Scheffer MC,

Castanheira FVES, Ferreira RG, Gehrke L, Alves-Filho JC, Silva LP,

Báfica A and Spiller F (2017)

Antibiotic-Induced Pathobiont Dissemination Accelerates Mortality in Severe Experimental Pancreatitis.

Front. Immunol. 8:1890. doi: 10.3389/fimmu.2017.01890
Although antibiotic-induced dysbiosis has been demonstrated to exacerbate intestinal inflammation, it has been suggested that antibiotic prophylaxis may be beneficial in certain clinical conditions such as acute pancreatitis (AP). However, whether broadspectrum antibiotics, such as meropenem, influence the dissemination of multidrugresistant (MDR) bacteria during severe AP has not been addressed. In the currently study, a mouse model of obstructive severe AP was employed to investigate the effects of pretreatment with meropenem on bacteria spreading and disease outcome. As expected, animals subjected to biliopancreatic duct obstruction developed severe AP. Surprisingly, pretreatment with meropenem accelerated the mortality of AP mice (survival median of 2 days) when compared to saline-pretreated AP mice (survival median of 7 days). Early mortality was associated with the translocation of MDR strains, mainly Enterococcus gallinarum into the blood stream. Induction of AP in mice with guts that were enriched with E. gallinarum recapitulated the increased mortality rate observed in the meropenempretreated AP mice. Furthermore, naiive mice challenged with a mouse or a clinical strain of $E$. gallinarum succumbed to infection through a mechanism involving toll-like receptor-2. These results confirm that broad-spectrum antibiotics may lead to indirect detrimental effects during inflammatory disease and reveal an intestinal pathobiont that is associated with the meropenem pretreatment during obstructive AP in mice.

Keywords: experimental acute pancreatitis, meropenem-induced pathobiont, Enterococcus gallinarum, microbiota, sepsis, antibiotics

\section{INTRODUCTION}

Gut microbiota have emerged as an important hub in the regulation of the inflammatory response (1). Accordingly, a number of conditions, such as rheumatoid arthritis, diabetes, and inflammatory bowel disease, have been associated with gut dysbiosis (2). Although it is difficult to distinguish whether dysbiosis is the cause or consequence of inflammation, a body of evidence has suggested that the use

Abbreviations: AP, acute pancreatitis; BDO, biliopancreatic duct obstruction; MDR, multidrug-resistant; Sham, shamoperated; BW, body weight; CFU, colony-forming units; VRE, vancomycin-resistant enterococci. 
of antibiotics can cause dysbiosis, leading to the dissemination of microbiota-derived multidrug-resistant (MDR) bacteria and poor inflammatory disease outcomes (3-5). For example, using a mouse model of intestinal inflammation induced by dextran sodium sulfate, Ayres and co-workers demonstrated that an antibiotic treatment lead to gut proliferation and systemic spreading of an MDR Escherichia coli strain, resulting in the rapid death of mice (3). In another study, Knoop et al. (5) demonstrated that a single dose of antibiotics induces dysbiosis-mediated bacterial translocation and worsens the dextran sodium sulfate-induced inflammatory response. These two examples indicate that certain antibiotics can play a detrimental role in intestinal inflammation. However, whether antibiotic-induced dysbiosis plays a role in the severity of other life-threatening inflammatory conditions, such as acute pancreatitis (AP), is less understood.

Acute pancreatitis is a systemic inflammatory response that is predominantly caused by obstruction of the pancreatic duct by gallstones and has a worldwide incidence of approximately 15 cases per 100,000 individuals per year (6). Twenty percent of AP patients will develop severe necrotic AP, and the combination of multiple organ failure and infection of the necrotic pancreas leads to mortality in up to $43 \%$ of patients (7). Therefore, a prophylactic antibiotic management regimen has been proposed to prevent infected pancreatic necrosis in the 1990s (8). The broad-spectrum carbapenems, such meropenem, are frequently used in the prophylaxis of AP patients because of their higher penetration of pancreatic tissue compared to other antibiotics (9-13). Carbapenems are also frequently used in septic patients as an empiric treatment prior to bacterial identification (14). Nowadays, guidelines for the management of AP do not recommend antibiotic prophylaxis in AP (15). However, this information is not precisely followed in clinical practice since antibiotic prophylaxis is still worldwide used in a fraction of AP patients (16-20). The benefits of antibiotic prophylaxis for patients with severe AP remain controversial. For instance, Dellinger et al. showed that prophylaxis treatment with meropenem did not significantly decrease pancreatic or peripancreatic infection, mortality, or the requirement for surgical intervention (21). In contrast, Rokke et al. demonstrated that a prophylactic treatment with a related drug, imipenem, decreased the rates of septic complications without affecting mortality or the need for surgical intervention (22). In a meta-analysis that included 11 studies with a total of 864 patients, Lim et al. found no significant difference in the incidence of infected pancreatic necrosis in patients subjected to antibiotic prophylaxis (23). Although these observations suggest that antibiotic prophylaxis or treatment of AP may be beneficial in some but not all cases, whether antibiotics influence the disease severity and spread of MDR pathobionts remains to be investigated. To date, only a few studies have evaluated the effects of meropenem on the outcome of experimental AP $(24,25)$ and the identities of the resistant strains that are selected by meropenem in patients or in experimental AP have not been addressed.

In the present study, an established biliopancreatic duct obstruction (BDO) model of AP was employed (26) to study whether meropenem pretreatment influences bacterial dissemination and disease outcome during severe AP. The results presented here show that meropenem pretreatment induces dissemination of gut MDR bacterial species, mainly Enterococcus gallinarum, which is associated with an accelerated mortality of AP mice. Furthermore, the mortality induced by E. gallinarum involves a TLR2-dependent pathway. These data reveal E. gallinarum as a pathobiont in severe experimental AP that emerges during meropenem pretreatment.

\section{MATERIALS AND METHODS}

\section{Mice}

Care and treatment of the animals were based on the Guide for the Care and Use of Laboratory Animals (27). Specific-pathogenfree $(\mathrm{SPF})$ male and female, Balb/C, C57BL/6 wild-type (Wt), and C57BL/6-TLR2-deficient (TLR2 $\left.{ }^{-/-}\right)(8-10$ weeks old) mice were housed under SPF conditions at the Animal Facility of the Department of Microbiology, Immunology and Parasitology from Federal University of Santa Catarina (UFSC). A total of 641 mice were used in this study. C57BL/6 Wt and Balb/C mice were purchased from Jackson Laboratory. TLR2 ${ }^{-/-}$mice generated by Dr. Shizuo Akira (Osaka University, Japan) (28) were a kind gift from Ricardo T. Gazzinelli (Federal University of Minas Gerais, Brazil). Mice were housed in cages at $21 \pm 2^{\circ} \mathrm{C}$ with free access to water and food. All animal experiments were approved by the Animal Welfare Committee of the UFSC (PP00880).

\section{AP Model}

Acute pancreatitis was induced by BDO, as described (26). Briefly, mice were anesthetized with xylazine ( $2 \mathrm{mg} / \mathrm{kg}$, i.p.) followed by isoflurane (3-5 vol\%). A 1-cm midline incision was made in the anterior abdomen, and the biliopancreatic duct was exposed at its orifice in the duodenal wall. The duct was dissected, and a tourniquet consisting of a cotton sewing and $2 \mathrm{~mm}$ of a P10 cannula was looped around the biliopancreatic duct adjacent to the duodenal wall. In the sham-operated (Sham) animals, the biliopancreatic duct was dissected but not obstructed. All animals received $1 \mathrm{~mL}$ of saline subcutaneously immediately after surgery. The obstructive model employed in the present study mimics the mechanical obstruction of the bile and pancreatitic ducts induced by biliar gallstones in AP patients, one of the main etiology of AP (6). The obstructive model of AP leads to disease development by self-mediators, which is a better representation of the natural course of the disease when compared to other models of severe AP, when chemical agents are intraductally administrated $(24,25)$.

\section{Determination of Serum Biochemical Markers}

Colorimetric assay kits were used to determine the serum activity of alanine aminotransferase, aspartate aminotransferase, amylase, lipase, alkaline phosphatase, and lactate dehydrogenase and the serum concentrations of bilirubin, urea, and creatinine (Labtest Diagnóstica, Brazil).

\section{Meropenem Treatments}

Mice were pretreated or treated intraperitoneally (i.p.) with saline or meropenem (Eurofarma, SP, Brazil, $100 \mathrm{mg} / \mathrm{kg}, 12 / 12 \mathrm{~h}$ ) for 
3 days and then subjected to surgery. The surgical procedure was performed $12 \mathrm{~h}$ after the last dose in the pretreated groups, and posttreatment started $12 \mathrm{~h}$ after surgery. Mice were also pretreated with meropenem for 3 or 5 days ( 30 or $100 \mathrm{mg} / \mathrm{kg}, 12 / 12 \mathrm{~h}$ ) to evaluate the tissue injury induced by the antibiotic treatment.

\section{Clindamycin/Ceftriaxone Treatment}

Mice were pretreated i.p. (12/12 h) with saline or clindamycin (Hipolabor, MG, Brazil, $25 \mathrm{mg} / \mathrm{kg}$ ) plus ceftriaxone (União Química, SP, Brazil, $30 \mathrm{mg} / \mathrm{kg}$ ) for 3 days and then subjected to surgery.

\section{Microbiota Enrichment}

To reduce the intestinal bacterial community, mice were treated with a cocktail of broad-spectrum antibiotics, as described previously (29). Animals were first exposed to amphotericin-B (Sigma-Aldrich, St. Louis, MO, USA, $1 \mathrm{mg} / \mathrm{kg}$ body weight, BW) delivered by gavage during 3 days, 12/12 h. From days 3 to 5 , ampicillin (Sigma-Aldrich, $1 \mathrm{mg} / \mathrm{mL}$ ) was added into the drinking water, and the mice were gavaged $12 / 12 \mathrm{~h}$ with a cocktail of antibiotics consisting of vancomycin (Sigma-Aldrich, $50 \mathrm{mg} / \mathrm{kg}$ BW), neomycin (Sigma-Aldrich, $100 \mathrm{mg} / \mathrm{kg} \mathrm{BW),} \mathrm{metronidazole}$ (Sigma-Aldrich, $100 \mathrm{mg} / \mathrm{kg} \mathrm{BW}$ ), and amphotericin-B (1 mg/kg BW). Additionally, from days 3 to 15, mice were i.p.-treated daily, with ciprofloxacin (Sigma-Aldrich, $50 \mathrm{mg} / \mathrm{kg} \mathrm{BW).} \mathrm{From} \mathrm{days} 16$ to 27 , mice were gavaged daily with $100 \mu \mathrm{L}(100 \mathrm{mg} / \mathrm{mL})$ of a feces suspension or with $100 \mu \mathrm{L}\left(1 \times 10^{8}\right.$ colony-forming units, CFUs $)$ of an E. gallinarum suspension. Fresh feces were collected from naïve mice, homogenized in sterile PBS and decanted for $30 \mathrm{~min}$ at RT. Animals were then exposed to supernatants of the feces suspension. E. gallinarum was cultivated in brain-heart infusion liquid medium at $37^{\circ} \mathrm{C}$ until an optical density of 0.60 at $600 \mathrm{~nm}$ was reached, and the bacteria were washed three times with PBS prior to animal administration. On day 28 , mice were subjected to Sham or AP induction.

\section{Bacterial Counts}

The bacterial count was determined as previously described (30). Briefly, samples were collected under sterile conditions, and $10 \mu \mathrm{L}$ of serial dilutions were seeded on agar dishes containing Muller-Hinton, blood agar Muller-Hinton, or bile esculin azide agar with $6 \mu \mathrm{g} / \mathrm{mL}$ of vancomycin (Difco Laboratories, Detroit, MI, USA) and grown at $37^{\circ} \mathrm{C}$ aerobically for $24 \mathrm{~h}$. The lumina of the intestinal samples were washed with PBS for intestinal CFU quantification. The results were expressed as the mean \pm SEM log of CFU per milliliter, grams of feces, or milligrams of tissue.

\section{Bacterial Identification}

We identified bacterial species using biochemical and microbiological methods, as described (31) and using the Vitek2 automated system (bioMérieux, see Tables S1-S8 in Supplementary Material for details regarding the bacterial identification).

\section{Colony PCR}

Individual colonies of E. coli and E. gallinarum were resuspended in sterile PBS and boiled for $10 \mathrm{~min}$. These samples were used for PCR analysis with the following primers for the vanC1 gene: F_5'GGTATCAAGGAAACCTC3' and R_5'CTTCCGCC ATCATAGCT3' (32). PCR was performed on a Mastercycler Gradient $^{\mathrm{TM}}$ thermocycler (Eppendorf, Germany) with the following conditions: $95^{\circ} \mathrm{C}(10 \mathrm{~min})$ followed by 35 cycles of $95^{\circ} \mathrm{C}$ $(1 \mathrm{~min})$, annealing at $54^{\circ} \mathrm{C}(30 \mathrm{~s}), 72^{\circ} \mathrm{C}(33 \mathrm{~s})$, with a final extension step at $72^{\circ} \mathrm{C}(5 \mathrm{~min})$. The concentration of magnesium used was $2.0 \mathrm{mM}$.

\section{Antibiotic Susceptibility Assays}

Enterococcus gallinarum susceptibility to vancomycin, clindamycin, streptomycin, ampicillin, and meropenem was determined using a disk diffusion or Etest assay. E. gallinarum was grown in brain-heart infusion liquid medium at $37^{\circ} \mathrm{C}$ until an optical density of 0.60 at $600 \mathrm{~nm}$ was reached, and aliquots (including a 0.5 McFarland standard) of the cultures were spread onto Muller-Hinton agar plates; 6-mm Whatman disks loaded with the appropriate antibiotic were added to the agar. Plates were incubated overnight at $37^{\circ} \mathrm{C}$, and the zone of bacterial growth inhibition was measured.

\section{E. gallinarum Infection}

Enterococcus gallinarum (FMC012174) was isolated from the blood of the AP mice that were pre-exposed to meropenem. The clinical strain of E. gallinarum (UH-FMC001) was isolated from the blood of a patient with sepsis and was a gift from the Microbiology Laboratory, University Hospital, UFSC. The E. gallinarum strains were grown in brain-heart infusion liquid medium at $37^{\circ} \mathrm{C}$ until an optical density of 0.60 at $600 \mathrm{~nm}$ was reached, and the strains were washed three times and resuspended with PBS. Six hours later, the AP induction mice were intravenously (i.v.) treated with $100 \mu \mathrm{L}$ of saline, $100 \mu \mathrm{L}$ of $1 \times 10^{8} \mathrm{CFU}$ of live E. gallinarum or $100 \mu \mathrm{L}$ of $1 \times 10^{8} \mathrm{CFU}$ of heat-killed E. gallinarum. Samples of E. gallinarum were boiled for $15 \mathrm{~min}$, and no bacterial growth was observed in these samples on the blood agar dishes $\left(37^{\circ} \mathrm{C}, 24 \mathrm{~h}\right)$. In another experimental set, Wt or TLR2 ${ }^{-1-}$ naïve mice were i.p.-treated with $200 \mu \mathrm{L}$ of $1 \times 10^{9} \mathrm{CFU}$ of the live mouse or clinical strains of E. gallinarum.

\section{Histological Examination}

Mice were euthanized $24 \mathrm{~h}$ after surgery, and the pancreases were fixed by immersion in 5\% paraformaldehyde, dehydrated, and embedded in paraffin wax. Three-micron-thick sections were stained with hematoxylin and eosin for histological examination. The scoring criteria for edema, inflammatory cell infiltration, and necrosis were as follows: 0 , absent; 1 , mild (5-10\% of tissue); 2 , moderate ( $10-30 \%$ of tissue); and 3 , severe (30\% of the tissue). The mean \pm SEM represented the sum of scores (range from 0 to 9) of the overall damage to the pancreas. Blind histological assessments were performed by a pathologist.

\section{Leukocyte Migration to Peritoneal Cavity}

Leukocyte migration was assessed 1, 4, and $24 \mathrm{~h}$ after surgery, as described (33).

\section{Leukocyte Infiltration in Lung}

Lungs were perfused with PBS/EDTA $(1 \mathrm{mM})$ before harvest from mice. Samples were collected $16 \mathrm{~h}$ after the last treatment. 
Lungs were passed through 40- $\mu \mathrm{m}$ nylon cell strainers and single cell suspensions were centrifuged in $35 \%$ Percoll $^{\circledast}$ solution (315 mOsm/kg, Sigma-Aldrich) for $15 \mathrm{~min}$ at $700 \times g$ to enrich leukocytes populations. Pelleted cells were then collected, and erythrocytes were lysed. Single cell suspensions from individual mice were stained for flow cytometry analysis, as described (34). Cells were stained with anti-mouse antibodies (BD Pharmingen) to GR1 (clone RB6-8C5), CD11b (clone M1/70) and F4/80 (clone BM8). Data were collected using a FACSCanto II (BD Immunocytometry Systems) and analyzed using FlowJo software.

\section{Statistics}

Data are reported as the means \pm SEM of the values obtained from three independent experiments. The mean values for the different groups were compared by analysis of variance (ANOVA). If significance was determined, individual comparisons were subsequently tested with Bonferroni's $t$-test for unpaired values. Bacterial counts were analyzed by the Mann-Whitney $U$-test or unpaired $t$-test using a parametric test with Welch's correction. Survival curves were plotted using the Kaplan-Meier method and then compared using the log-rank method and Gehan-Wilcoxon test. Data were analyzed using GraphPad Prism version 6.00 for Mac (GraphPad Software, USA). A $P<0.05$ was considered significant.

\section{RESULTS}

\section{BDO Induces Severe AP}

Gallstone disease is one of the most common etiologies of AP (6). Therefore, we modeled obstructive AP with BDO. All mice subjected to BDO died within 6 days after surgery, whereas all sham-operated (Sham) mice survived (Figure 1A). Compared to Sham animals, BDO animals displayed a significant increase in serum amylase/lipase and alkaline phosphatase/ direct bilirubin, which are biomarkers associated with AP and biliary obstruction, respectively (Figures 1B-E). Additionally, we detected a significant augmentation of leukocytes in the peritoneal cavity of the AP mice compared to the Sham mice (Figure 1F). Histological examination of the pancreas indicated that the obstructive experimental AP model resembled major features of severe AP in patients (35). The pancreas from the Sham group showed a mean of histological scores of 1.75 (with a range from 0 to 2 ) with edema and inflammatory cell infiltration as the predominant characteristics (Figure 1G). Pancreatic tissue sections of the AP group exhibited a mean histological score of 5.0 (with a range from 3 to 7 ), characterized by diffuse acinar cell necrosis, inflammatory cell infiltration, and edema. These results confirm that the obstructive mouse model employed induces severe AP.

\section{Meropenem Treatment Accelerates the Mortality of AP Mice}

As meropenem is a broad-spectrum antibiotic used as a prophylactic treatment in severe AP (36), the effects of meropenem on the outcome of experimental AP were investigated. Posttreatment of AP C57BL/6 mice with meropenem significantly accelerated animal mortality (Figure 2A). As expected, all Sham mice treated with saline or meropenem survived (Figure 2A). To investigate the factor(s) underlying the observed mortality induced by meropenem in AP C57BL/6 mice, animals were pretreated with the antibiotic for 3 days, and AP was induced by BDO $12 \mathrm{~h}$ after the last dose. Meropenem-pretreated AP mice displayed a strong reduction in survival rate (median survival of 2 days) compared to saline-pretreated AP animals (median survival of 7 days, Figure 2B). In the two meropenem-exposed AP groups (posttreatment and pretreatment), the serum levels of amylase and lipase were equal to those in the saline-exposed AP mice (Figures 2C-F), suggesting that meropenem did not directly affect AP development.

As reported in previous studies $(37,38)$, treatment of naïve mice for 3 or 5 days did not increase the serum activities of alanine aminotransferase, aspartate aminotransferase, urea, creatinine, or lactate dehydrogenase (Figures S1A-E in Supplementary Material), indicating the faster mortality observed in the meropenem-treated animals was not due to acute toxicity mediated by this antibiotic. In addition, the effect of antibiotic on immune system activation was evaluated. Leukocyte infiltration in the lungs is a sensitive hallmark of systemic inflammation and a key step to lung injury in AP (39-42). Figure S2 in Supplementary Material shows that antibiotic treatment did not change the numbers of neutrophils $\left(\mathrm{GR} 1^{\text {high }} \mathrm{CD} 11 \mathrm{~b}^{+}\right)$and monocytes $\left(\mathrm{F} 4 / 80^{\text {high }} \mathrm{CD} 11 \mathrm{~b}^{\text {high }}\right)$ in lungs of naïve or Sham mice, however, significantly increased the $\mathrm{F} 4 / 80^{\text {high }} \mathrm{CD} 11 \mathrm{~b}^{\text {high }}$ cells in the lungs of AP mice. These results suggest whether antibiotic induced an activation of the immune system, it is not enough to generate a systemic inflammatory response in naïve or Sham mice. However, in the context of experimental AP, the antibiotic pretreatment could worsen the outcome of systemic inflammation.

Since antibiotic-induced bacterial dissemination has been associated with a poor inflammatory disease outcome $(3,5)$, the effect of the meropenem pretreatment on the CFU number in tissues and blood was investigated. The CFU numbers in the pancreas were similar in all groups (Figure 3A). In the spleen, the number of CFUs increased in the AP and meropenem-pretreated AP mice compared with the Sham groups but were similar between the AP and meropenem-pretreated AP mice (Figure 3B). However, $24 \mathrm{~h}$ after surgery, a significant increase in the CFU content in the blood was observed in meropenem-pretreated AP mice compared to AP mice (Figure 3C). The pictures provided in Figure 3C show an example of the high CFU content in the blood from meropenem-pretreated AP mice.

Compared to AP mice, meropenem-pretreated AP animals displayed approximately 10 times more CFUs in the small intestine but not in the colon or cecum (Figure S3 in Supplementary Material). Next, automated, classical biochemically based and microbiology-based methods were employed to identify the bacterial species. Approximately $80 \%$ of bacteria found in the small intestine were identified as E. gallinarum (Table S1 in Supplementary Material). The remaining 20\% of the bacteria identified were Staphylococcus epidermidis, Staphylococcus lentus, and Bacillus spp. (Tables S2, S3, and S8 in Supplementary Material). 

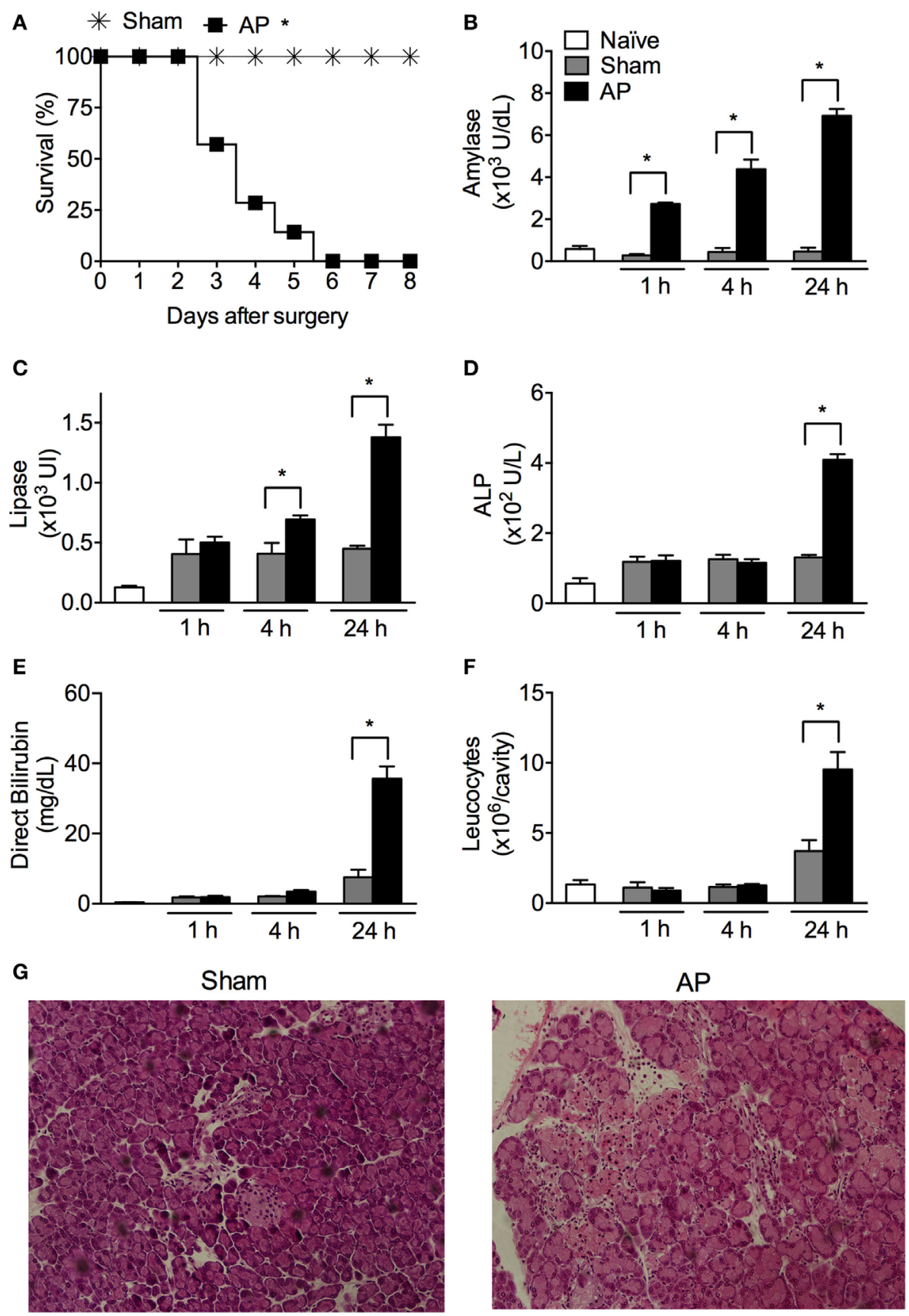

FIGURE 1 | Obstruction of the biliopancreatic duct triggers severe acute pancreatitis (AP) in mice. (A) Survival of C57BL/6 mice subjected to AP ( $n=31$ ) or the sham operation (Sham, $n=16$ ). Serum concentrations of amylase (B), lipase (C), alkaline phosphatase (ALP) (D), direct bilirubin (E), and total leukocytes (F) in the peritoneal cavity lavage were evaluated 1, 4, and 24 h after surgery in AP $(n=48)$, Sham $(n=27)$, or naïve mice $(n=27)$. (G) Histomorphological analysis of pancreas collected from mice $24 \mathrm{~h}$ after Sham or AP induction. These experiments were performed independently three times. ${ }^{\star} P<0.05$ compared with Sham mice.

Importantly, E. gallinarum was also found in high abundance in the blood samples of $100 \%$ of meropenem-pretreated AP mice (9/9), indicating bacterial translocation following AP disease (Figure 3D). Although in lower frequency, Enterobacter cloacae complex strains (6/9) and Staphylococcus warneri (3/9) were observed in the blood of antibiotic-treated AP mice (Figure 3D;
Tables S1, S4, and S5 in Supplementary Material). E. cloacae complex (3/9), Raoultella planticola (3/9), and S. lentus (6/9) were identified in saline-pretreated AP mice (Figure 3D; Tables S3, S4, and S6 in Supplementary Material). These results suggest a major change in the bacterial profile of the blood from meropenempretreated AP animals and reveal the emergence of E. gallinarum. 


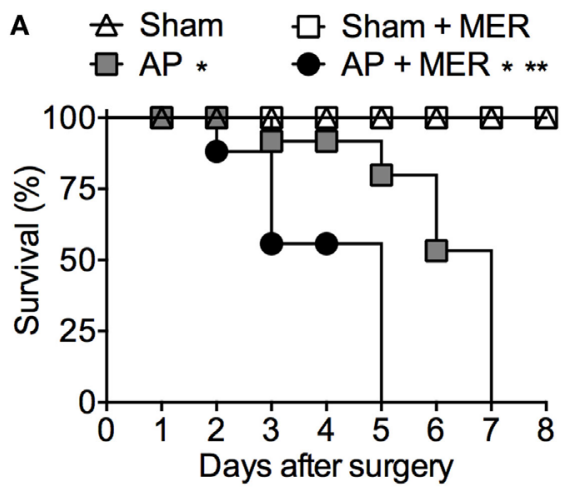

c
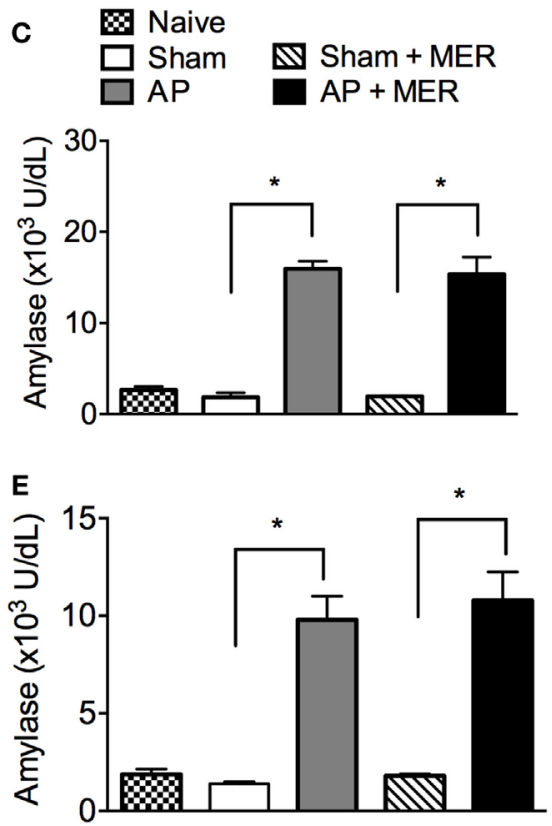

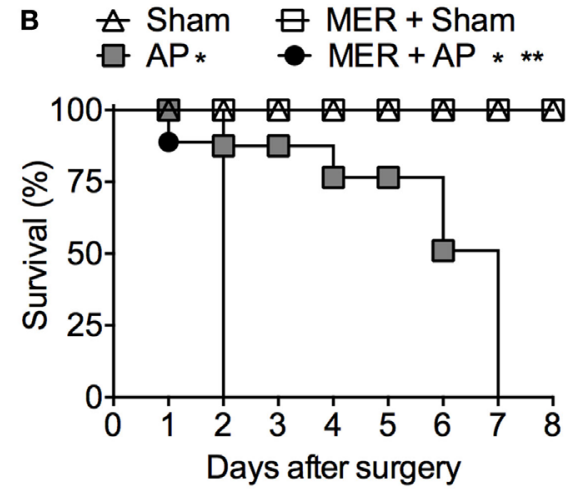

D

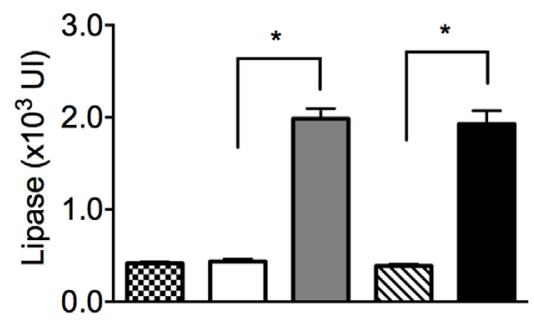

$\mathbf{F}$

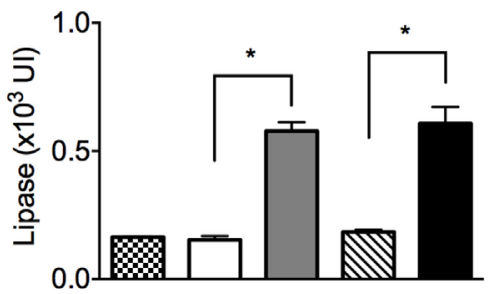

FIGURE 2 | Meropenem accelerates the mortality rate of mice with acute pancreatitis (AP). (A) Survival rate of mice subjected to the sham operation (Sham, $n=9$ ), Sham mice posttreated with meropenem (Sham + MER, $100 \mathrm{mg} / \mathrm{kg}$, i.p., 12/12 h, 3 days, $n=9$ ), AP posttreated with saline (200 $\mu \mathrm{L}$, i.p., $12 / 12 \mathrm{~h}, 3$ days, $n=15)$, or AP posttreated with meropenem (AP + MER, $100 \mathrm{mg} / \mathrm{kg}$, i.p., $12 / 12 \mathrm{~h}, 3$ days, $n=25$ ). Posttreatments started $12 \mathrm{~h}$ after the surgeries. ${ }^{*} P<0.0001$ compared with the Sham groups; ${ }^{\star \star} P<0.0001$ compared with the AP mice. (B) Survival rate of mice subjected to the procedures described in (A), with a modification that saline and meropenem were given as a pretreatment (100 mg/kg, i.p., 12/12 h, 3 days). Surgeries were performed $12 \mathrm{~h}$ after the last dose of saline or meropenem (Sham $n=9$, Sham + MER $n=12$, AP $n=16$, and AP + MER $n=31$ ). ${ }^{*} P<0.0001$ compared with the Sham groups; ${ }^{* *} P<0.0001$ compared with the AP mice. These experiments were performed independently three times. Serum concentrations of (C) amylase and (D) lipase of mice subjected to Sham $(n=6)$,

Sham + MER $(n=6), \operatorname{AP}(n=10)$, and AP + MER $(n=12)$. Samples were collected $60 \mathrm{~h}$ after surgery. Serum concentrations of $(\mathbf{E})$ amylase and $(\mathbf{F})$ lipase in mice subjected to Sham $(n=6)$, MER + Sham $(n=6), \operatorname{AP}(n=10)$, and MER + AP $(n=10)$. Samples were collected $24 \mathrm{~h}$ after surgery. ${ }^{*} P<0.0001$ compared with the Sham or naïve mice. These experiments were performed independently two times.

Since E. gallinarum was the most frequent species observed in the blood of meropenem-pretreated AP mice, this result was investigated further. E. gallinarum was positive for the VanC1 gene (Figure S4 in Supplementary Material) (43) and showed low resistance to vancomycin $(\mathrm{MIC}=6-8 \mu \mathrm{g} / \mathrm{mL})$, intermediate resistance to meropenem (zone of inhibition $=16 \mathrm{~mm}$ ), and high resistance to clindamycin, ceftriaxone, and streptomycin (zone of inhibition $=0 \mathrm{~mm}$ ), but E. gallinarum was sensitive to ampicillin (zone of inhibition $=30 \mathrm{~mm}$ ). Notably, pretreatment (12/12 h, 3 days) of C57BL/6 and Balb/C mice with clindamycin and ceftriaxone also induced major reductions in the survival rates of AP mice (Figure S5 in Supplementary Material).

\section{E. gallinarum-Recolonized Mice Show Increased Disease Severity following AP}

To investigate the existence of a possible link between E. gallinarum and the severity of AP, the intestinal microbiota of mice were suppressed with a cocktail of broad-spectrum antibiotics (29) and repopulated with a fecal or E. gallinarum suspension (Figure 4A). As expected (29), the cocktail of broad-spectrum antibiotics 

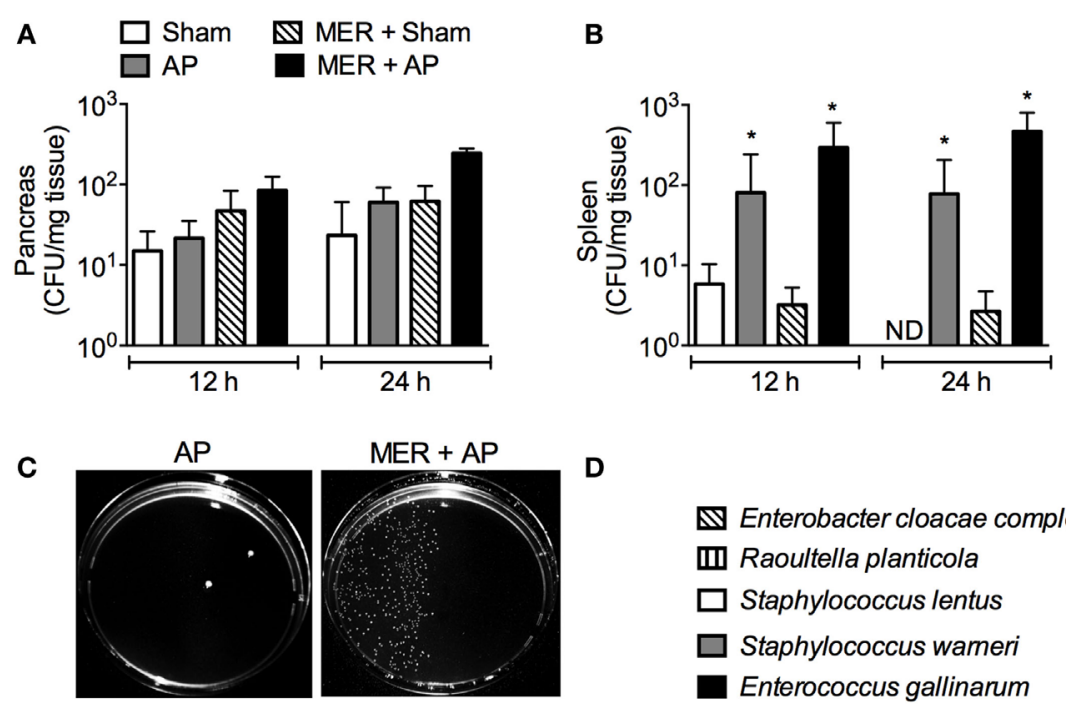

D
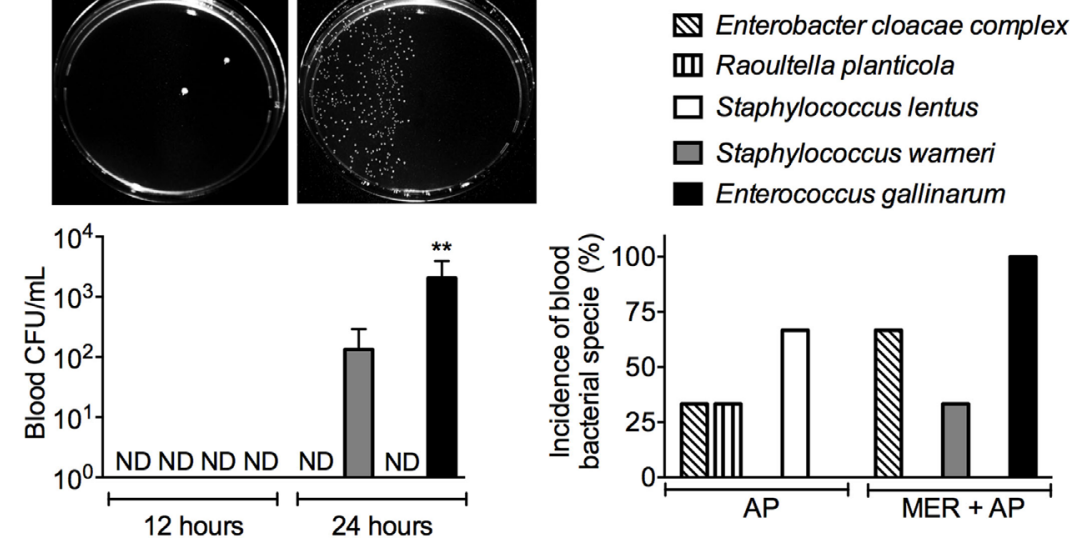

FIGURE 3 | Meropenem pretreatment increases the colony-forming units (CFUs) in the blood of mice with acute pancreatitis (AP). The bacterial load in the (A) pancreas, (B) spleen, and $\mathbf{( C )}$ blood was evaluated 12 or $24 \mathrm{~h}$ after the surgeries in samples harvested from the pretreated mice. ${ }^{\star} P<0.05$ compared with the Sham mice. ${ }^{\star \star} P<0.05$ compared with the AP mice. Sham $(n=9)$, MER + Sham $(n=9)$, AP $(n=15)$, and MER + AP $(n=15)$. These experiments were performed independently three times. The pictures of the Mueller-Hinton agar plates provided in panel (C) show an example of the bacterial load in the blood samples from the AP or meropenem-pretreated AP mice $24 \mathrm{~h}$ after the surgeries. The pictures were converted to black and white, and the contrast of the whole picture was increased using the Adobe Photoshop 7.0 software (see original pictures in Figure S6 in Supplementary Material). (D) The CFUs that increased in the blood samples from AP or MER + AP were identified using the Vitek2 method. The results were expressed as the incidence of bacterial species in the blood (we analyzed 9 samples from a total of 15 mice). ND, not detectable.

depleted all fecal cultivable aerobic bacteria. Oral administration of fecal or E. gallinarum suspensions to antibiotic-treated mice resulted in high levels of intestinal recolonization (Figure 4B). Moreover, fecal samples from mice treated orally with E. gallinarum, but not with feces, contained $\sim 10^{8} \mathrm{CFU} / \mathrm{g}$ (Figure $4 \mathrm{C}$ ) in the vancomycin-resistant enterococci (VRE) selective agar medium. All of these colonies were E. gallinarum as confirmed using the Vitek2 method. Strikingly, compared to mice recolonized with the fecal suspension, animals exposed to E. gallinarum displayed enhanced mortality during AP onset (Figure 4D). This effect was associated with E. gallinarum translocation into the blood (Figure 4E). Furthermore, intravenous administration of live E. gallinarum in AP mice induced significantly higher mortality rates compared to AP animals administered either saline or dead E. gallinarum (Figure 4F). Taken together, these results indicate that E. gallinarum is sufficient to exacerbate the severity of AP.

To determine if isolated E. gallinarum induces sepsis in naïve mice, Wt animals were challenged with these bacteria, and the survival rates were analyzed. All mice exposed to a systemic challenge with E. gallinarum died within 3 days of the infection (Figure 4G). Since E. gallinarum could induce cellular activation through a TLR2/6-dependent pathway (44) and since this receptor plays a pivotal role in mortality during severe sepsis (30), we challenged TLR2-deficient mice with E. gallinarum. Figure 4G shows that $\sim 30 \%$ of TLR2-deficient animals survived after a lethal challenge with E. gallinarum. Similarly, TLR2-deficient mice were found to be partially resistant following exposure to a clinical strain of E. gallinarum isolated from a septic patient (Figure $4 \mathbf{H}$ ). These data suggest that TLR2 is involved in the host pathogenesis of the E. gallinarum infection.

\section{DISCUSSION}

In the present study, we found that meropenem pretreatment accelerates the mortality of mice subjected to severe AP. These data provide evidence that the mortality of AP mice is associated with meropenem-induced translocation of pathobionts such as E. gallinarum. These results reinforce and extend previous observations showing the potential harmful effects of antibiotics in inflammatory disease $(3,5)$.

Severe AP was induced by obstruction of the common biliopancreatic duct in mice, which is thought to be one of the best 
models resembling obstructive AP in patients. This model leads to severe AP characterized by necrosis of the pancreas and a high index of mortality (45). Pretreatment of AP mice with meropenem did not prevent infection, but instead induced MDR bacterial translocation into the blood. Our results diverge from previous studies demonstrating that meropenem prophylaxis reduces bacteremia, infection of the pancreatic tissue, and mortality of AP animals $(24,25)$. These studies administrated a single dose of meropenem in rats with AP induced by chemical agents. Several factors could account for these apparently conflicting results, but

A

Feces

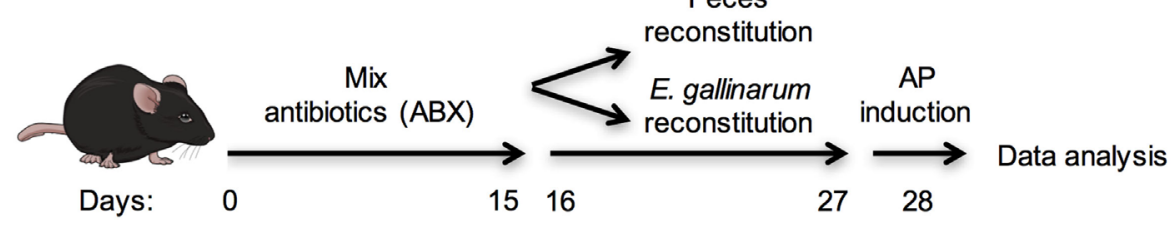

B

- $A B X+$ Feces reconstitution

$\theta \mathrm{ABX}+$ E. gallinarum reconstitution

C

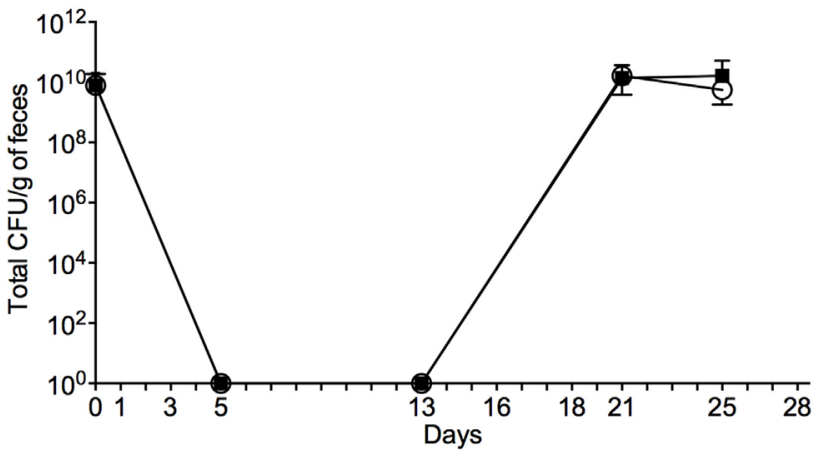

Feces reconstitution

E. gallinarum reconstitution
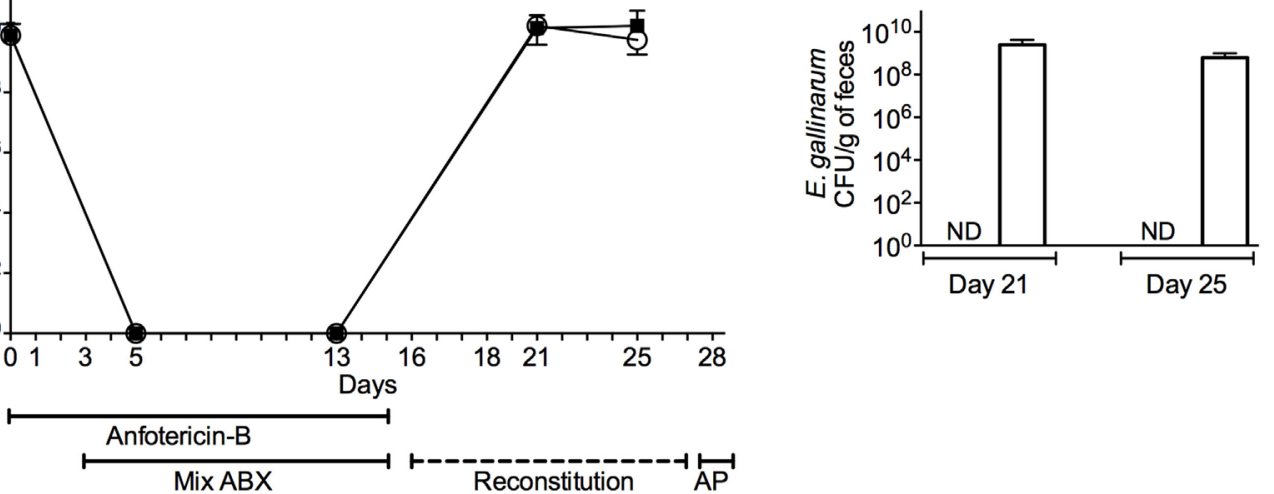

D
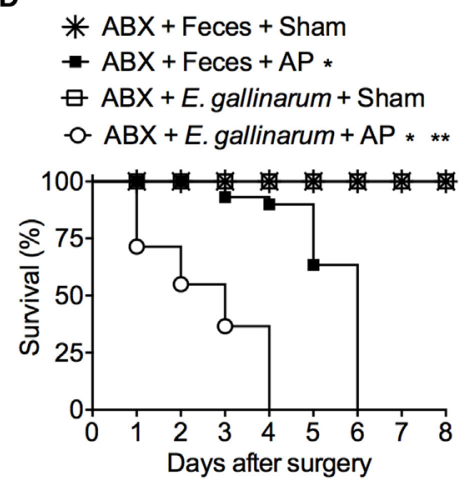

G

- Wt E. gallinarum

$\square$ TLR2-I-E. gallinarum *

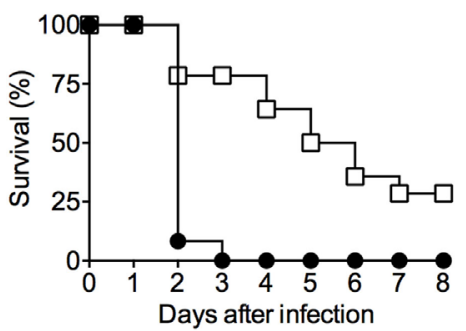

E

$\mathrm{ABX}+$ Feces $+\mathrm{AP}$

$\square \mathrm{ABX}+$ E. gallinarum $+\mathrm{AP}$

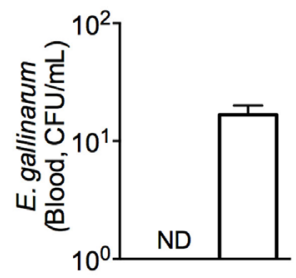

H

- Wt E. gallinarum from septic patient

$\square$ TLR2 ${ }^{-1-}$ E. gallinarum from septic patient **

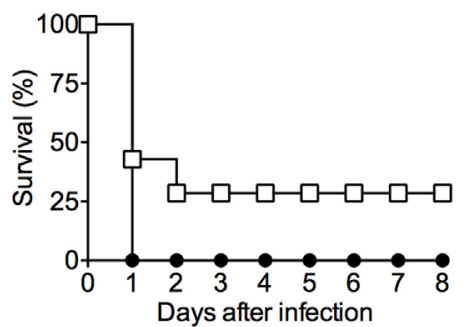

FIGURE 4 | Continued 
FIGURE 4 | Microbiota enrichment with Enterococcus gallinarum induces enhanced mortality of acute pancreatitis (AP) mice. (A) Experimental design for the intestinal bacterial community reduction, intestinal bacterial reconstitution, AP induction, and data analysis (mice design from https://mindthegraph.com). (B) Fresh fecal samples were collected from mice prior to the experiment (day 0 ) and spread on Mueller-Hinton agar plates; the results were expressed as colony-forming unit $(\mathrm{CFU}) / \mathrm{g}$ of feces. Beginning on the following day (day 1) and continuing to day 15, mice were exposed to a mix of antibiotics (ABX). From day 16 to day 27 , mice were gavaged daily with $100 \mu \mathrm{L}(100 \mathrm{mg} / \mathrm{mL})$ of the feces suspension or with $100 \mu \mathrm{L}\left(1 \times 10^{8} \mathrm{CFU}\right)$ of the E. gallinarum suspension (see Materials and Methods). Fresh feces were also collected from mice on days 5, 13, 21, and 25 and spread on Mueller-Hinton agar plates. (C) Fresh feces collected on days 21 and 25 were spread on bile esculin azide agar plates with $6 \mu \mathrm{g} / \mathrm{mL}$ of vancomycin, and the CFUs that grew on samples from mice treated with the E. gallinarum suspension were identified as E. gallinarum using the Vitek2 method. The results were expressed as E. gallinarum CFU/g of feces. (D) The survival rates of the Sham or AP mice that received feces or the E. gallinarum suspension (Sham $n=9$, MER + Sham $n=9$, AP $n=15$, and MER + AP $n=15$ ); ${ }^{*} P<0.0001$ compared with the Sham groups; ${ }^{* *} P<0.0001$ compared with AP mice. (E) Blood samples were collected $24 \mathrm{~h}$ after surgery and spread on bile esculin azide agar plates with $6 \mu \mathrm{gg} / \mathrm{mL}$ of vancomycin. CFUs grew on the samples from mice treated with the E. gallinarum suspension were identified as $E$. gallinarum using the Vitek2 method. The results were expressed as E. gallinarum CFU/mL of blood. (F) The survival rates of the AP mice treated intravenously (i.v.) with saline, heat-killed (dead, $n=15$ ) E. gallinarum $\left(1 \times 10^{8} \mathrm{CFU} / \mathrm{mouse}, n=15\right)$ or live $E$. gallinarum $\left(1 \times 10^{8} \mathrm{CFU} / \mathrm{mouse}, n=15\right)$ and Sham mice treated i.v. with live $E$. gallinarum $\left(1 \times 10^{8} \mathrm{CFU} / \mathrm{mouse}\right.$ $n=8) ;{ }^{*} P<0.0001$ compared with $\mathrm{AP}+$ dead $E$. gallinarum or AP + saline. The survival rates of C57BL/6 (Wt) and TLR2-deficient (TLR2 ${ }^{-/-}$) mice challenged with intraperitoneal administration of $\mathbf{( G )}$ E. gallinarum $(1 \times 10 \%$ mouse, $n=15)$ isolated from mice or $\mathbf{( H )} E$. gallinarum $\left(1 \times 10^{\%} / \mathrm{mouse}, n=15\right)$ isolated from a septic patient. ${ }^{\star} P<0.0001$ compared with Wt $E$. gallinarum. ${ }^{\star \star} P<0.01$ compared with Wt $E$. gallinarum from septic patient. These experiments were performed independently three times. ND, not detectable.

we speculate the microbiota differences between these species could be a key factor for the different results, since the antibioticinduced emergence of MDR bacteria appears to be dependent of the animal source even in the same mice strain (3). Indeed, meropenem treatment-induced fast mortality of AP mice was observed in C57BL/6 and Balb/C mice house in our animal facility, but not in Swiss mice from a non-SPF animal facility where E. gallinarum is not prevalent in feces of these mice (data not shown). Our results are consistent with studies showing that pretreatment with broad-spectrum antibiotics induce dissemination of pathobionts by changing the microbiota composition (3-5). The mechanism involved in the spread of opportunistic bacteria from microbiota is poorly understood. However, antibioticdecreased susceptible bacterial species could negatively impact the generation of antimicrobial peptides such as $\alpha$-defensins, cryptdins, and the C-type lectin Reg3 $\gamma$, which selectively kills Gram-positive bacteria (46-48).

Although E. gallinarum is a component of the mouse microbiota (49), only blood samples from meropenem-pretreated AP mice contained this bacterium. This evidence suggests that meropenem pretreatment favored bacterial growth following E. gallinarum dissemination and increased the mortality of AP mice. Accordingly, the infection of the AP mice or the microbiota enrichment with E. gallinarum recapitulated the accelerated mortality observed in the meropenem-pretreated AP mice. Pretreatment of AP mice with clindamycin and ceftriaxone, two antibiotics to which E. gallinarum showed resistance in vitro, also reproduced the meropenem effect on mortality. Because bacterial species other than E. gallinarum were identified on the blood of meropenem-pretreated AP mice, we cannot rule out the involvement of other bacteria species in the meropenem-accelerated mouse mortality. Nevertheless, our results indicate that E. gallinarum is sufficient to induce severe disease in AP mice.

Enterococcus gallinarum promoted lethality in naïve mice through a TLR2-dependent mechanism. This result is in agreement with previous reports, which demonstrated that the absence of a single TLR does not impair the local inflammatory response but reduces the systemic inflammatory response (30). Therefore, it is possible that other receptors/mechanisms, such as TLR6 (44), are involved in the recognition of E. gallinarum at the point of the infection. Furthermore, some studies have shown a key role for TLRs and their endogenous agonists in the severity of AP (50-54). For example, Sharif and colleagues (51) observed a significant reduction in the severity of AP in TLR4 ${ }^{-/-}$mice $24 \mathrm{~h}$ after caerulein or L-arginine administration. In accordance, Awla and colleagues (53) found that pancreatic damage, neutrophil infiltration, and CXCL2 in lung and pancreas were significantly reduced in TLR4 ${ }^{-/-}$mice, but not in TLR2 ${ }^{-/-}$mice, $24 \mathrm{~h}$ after AP induction by taurocholate infusion. On the other hand, Pastor and colleagues (54) observed a similar severity of AP in TLR4 ${ }^{-1-}$ and Wt mice in the caerulein model. We did not observe a different mortality rate between TLR2 ${ }^{--}$and Wt mice in the obstructive model of AP (data not shown), suggesting that TLR2 does not play an important role in the final outcome of AP induced by biliopancreatitic duct obstruction. Nevertheless, the contribution of the gut microbiota diversity-TLRs axis in AP remains to be investigated.

Since the first report of bacteremia in humans by E. gallinarum (31), several VREs have been isolated from septic patients, and currently, they are a growing clinical problem (55). Infections by E. gallinarum have a low prevalence (1-3\%) between VREs, but because most of the clinical samples have been reported as Enterococcus sp., the prevalence of E. gallinarum may be underestimated (56). Despite its low prevalence, E. gallinarum is invasive and can induce severe disease including bacteremia, endocarditis, meningitis, and peritonitis (57-59). In addition, E. gallinarum may represent a harmful role for the host in providing a large reservoir for resistance genes (60).

The role of microbiota in the severity of experimental AP is not fully understood, although bacterial translocation from the small intestine is a key event in this process (61). Together with the spread of E. gallinarum into the bloodstream, the meropenem pretreatment of AP mice also increased E. gallinarum in the small intestine. Bacteria culture-based methods used in the present work in bacteria identification are a less sensitive method when compared with culture-independent molecular approaches, such as $16 \mathrm{~S}$ metagenomics $(62,63)$. Therefore, other bacteria species translocated into circulation or grew in low numbers in small intestine could be not detected by the conventional culture techniques. Even using less sensitive 
bacteria culture-based methods, a prevalent new pathobiont on the blood of meropenem-pretreated AP mice were identified. Accordingly, it has been demonstrated that antibiotic treatment of mice induces Enterococcus sp. colonization of the small intestine and a predominance of VREs in gut $(4,64)$. It might also be noted that E. gallinarum is an inhabitant of the small intestine in humans (65). In the context of pancreatic disease, a multi-hospital prospective clinical study showed that the intestinal population of Enterococcus is higher and more positively correlated with the serum levels of IL- 6 in severe AP than in mild AP (66), suggesting that the increase in Enterococcus contributes to the severity of this disease. Despite E. gallinarum has not been associated with gallstone-induced obstructive AP in patients, a retrospective analysis of 56 cases of bacteremia caused by E. casseliflavus or E. gallinarum found these pathogens to be associated with biliary tract disease (67).

The present study provides evidence that the meropeneminduced fast mortality of AP mice is associated with the translocation of pathobionts, such as E. gallinarum. Although the data presented here using a murine model cannot be translated to clinical practice, our findings highlight the need for prospective clinical studies to evaluate the effect of meropenem on the MDR bacterial incidence in AP patients.

\section{ETHICS STATEMENT}

Care and treatment of the animals were based on the Guide for the Care and Use of Laboratory Animals. All animal experiments were approved by the Animal Welfare Committee of the UFSC (PP00880).

\section{AUTHOR CONTRIBUTIONS}

FSS, FA, NS, LPS, LY, MS, FC, RF, LG, MV, and FS performed research, analyzed, and interpreted the data. JA-F and LPS contributed with analytic tools, data interpretation, and design of the work. $\mathrm{AB}$ and $\mathrm{FS}$ designed research, analyzed data, and wrote the paper. LKRS performed research, analyzed, and interpreted the data.

\section{ACKNOWLEDGMENTS}

The authors would like to thank Dr. Menin A, Dr. Smânia A, Morgana F, Mezzomo E, and Junkes A, for technical assistance.

\section{FUNDING}

CNPQ (407799/2012-5 and 449282/2014-7), CNPQ-PRONEX (1262/2012-9). AB received financial support from NIH-GRIP (TW008276), HHMI-ECS (55007412). FS, JA-F, AB, and LPS are CNPq-PQ fellows.

\section{SUPPLEMENTARY MATERIAL}

The Supplementary Material for this article can be found online at http://www.frontiersin.org/articles/10.3389/fimmu.2017.01890/ full\#supplementary-material.

\section{REFERENCES}

1. Kamada N, Seo SU, Chen GY, Nunez G. Role of the gut microbiota in immunity and inflammatory disease. Nat Rev Immunol (2013) 13:321-35. doi:10.1038/nri3430

2. Levy M, Kolodziejczyk AA, Thaiss CA, Elinav E. Dysbiosis and the immune system. Nat Rev Immunol (2017) 17:219-32. doi:10.1038/nri.2017.7

3. Ayres JS, Trinidad NJ, Vance RE. Lethal inflammasome activation by a multidrug-resistant pathobiont upon antibiotic disruption of the microbiota. Nat Med (2012) 18:799-806. doi:10.1038/nm.2729

4. Ubeda C, Taur Y, Jenq RR, Equinda MJ, Son T, Samstein M, et al. Vancomycinresistant Enterococcus domination of intestinal microbiota is enabled by antibiotic treatment in mice and precedes bloodstream invasion in humans. J Clin Invest (2010) 120:4332-41. doi:10.1172/JCI43918

5. Knoop KA, Mcdonald KG, Kulkarni DH, Newberry RD. Antibiotics promote inflammation through the translocation of native commensal colonic bacteria. Gut (2016) 65:1100-9. doi:10.1136/gutjnl-2014-309059

6. Yadav D, Lowenfels AB. The epidemiology of pancreatitis and pancreatic cancer. Gastroenterology (2013) 144:1252-61. doi:10.1053/j.gastro.2013.01.068

7. Petrov MS, Shanbhag S, Chakraborty M, Phillips AR, Windsor JA. Organ failure and infection of pancreatic necrosis as determinants of mortality in patients with acute pancreatitis. Gastroenterology (2010) 139:813-20. doi:10.1053/j.gastro.2010.06.010

8. Uomo G. Antibiotic treatment in acute pancreatitis. Rocz Akad Med Bialymst (2005) 50:116-21.

9. Saglamkaya U, Mas MR, Yasar M, Simsek I, Mas NN, Kocabalkan F. Penetration of meropenem and cefepim into pancreatic tissue during the course of experimental acute pancreatitis. Pancreas (2002) 24:264-8. doi:10.1097/ 00006676-200204000-00009

10. Pederzoli P, Bassi C, Vesentini S, Campedelli A. A randomized multicenter clinical trial of antibiotic prophylaxis of septic complications in acute necrotizing pancreatitis with imipenem. Surg Gynecol Obstet (1993) 176:480-3.

11. Bassi C, Falconi M, Talamini G, Uomo G, Papaccio G, Dervenis C, et al. Controlled clinical trial of pefloxacin versus imipenem in severe acute pancreatitis. Gastroenterology (1998) 115:1513-7. doi:10.1016/S0016-5085(98)70030-7

12. Manes G, Rabitti PG, Menchise A, Riccio E, Balzano A, Uomo G. Prophylaxis with meropenem of septic complications in acute pancreatitis: a randomized, controlled trial versus imipenem. Pancreas (2003) 27:e79-83. doi:10.1097/00006676-200311000-00018

13. Manes G, Uomo I, Menchise A, Rabitti PG, Ferrara EC, Uomo G. Timing of antibiotic prophylaxis in acute pancreatitis: a controlled randomized study with meropenem. Am J Gastroenterol (2006) 101:1348-53. doi:10.1111/j. 1572-0241.2006.00567.x

14. Brunkhorst FM, Oppert M, Marx G, Bloos F, Ludewig K, Putensen C, et al. Effect of empirical treatment with moxifloxacin and meropenem vs meropenem on sepsis-related organ dysfunction in patients with severe sepsis: a randomized trial. JAMA (2012) 307:2390-9. doi:10.1001/jama.2012.5833

15. Working Group IAP/APA Acute Pancreatitis Guidelines. IAP/APA evidence-based guidelines for the management of acute pancreatitis. Pancreatology (2013) 13:e1-15. doi:10.1016/j.pan.2013.07.063

16. Baltatzis M, Jegatheeswaran S, O'Reilly DA, Siriwardena AK. Antibiotic use in acute pancreatitis: global overview of compliance with international guidelines. Pancreatology (2016) 16:189-93. doi:10.1016/j.pan.2015.12.179

17. Baltatzis M, Mason JM, Chandrabalan V, Stathakis P, Mcintyre B, Jegatheeswaran S, et al. Antibiotic use in acute pancreatitis: an audit of current practice in a tertiary centre. Pancreatology (2016) 16:946-51. doi:10.1016/j. pan.2016.08.012

18. Mandal AK, Chaudhary S, Shrestha B, Paudel MS, Poudyal NS, Paudel BN, et al. Efficacy of prophylactic use of ciprofloxacin and metronidazole in mild and moderately severe acute pancreatitis. JNMA J Nepal Med Assoc (2017) 56:207-10.

19. Nesvaderani M, Eslick GD, Faraj S, Vagg D, Cox MR. Study of the early management of acute pancreatitis. ANZ J Surg (2017) 87:805-9. doi:10.1111/ ans. 13330 
20. Mourad MM, Evans R, Kalidindi V, Navaratnam R, Dvorkin L, Bramhall SR. Prophylactic antibiotics in acute pancreatitis: endless debate. Ann R Coll Surg Engl (2017) 99:107-12. doi:10.1308/rcsann.2016.0355

21. Dellinger EP, Tellado JM, Soto NE, Ashley SW, Barie PS, Dugernier T, et al. Early antibiotic treatment for severe acute necrotizing pancreatitis: a randomized, double-blind, placebo-controlled study. Ann Surg (2007) 245:674-83. doi:10.1097/01.sla.0000250414.09255.84

22. Rokke O, Harbitz TB, Liljedal J, Pettersen T, Fetvedt T, Heen LO, et al. Early treatment of severe pancreatitis with imipenem: a prospective randomized clinical trial. Scand J Gastroenterol (2007) 42:771-6. doi:10.1080/00365520601173855

23. Lim CL, Lee W, Liew YX, Tang SS, Chlebicki MP, Kwa AL. Role of antibiotic prophylaxis in necrotizing pancreatitis: a meta-analysis. J Gastrointest Surg (2015) 19:480-91. doi:10.1007/s11605-014-2662-6

24. Fritz S, Hartwig W, Lehmann R, Will-Schweiger K, Kommerell M, Hackert T, et al. Prophylactic antibiotic treatment is superior to therapy on-demand in experimental necrotising pancreatitis. Crit Care (2008) 12:R141. doi:10.1186/ cc7118

25. Catena F, Ansaloni L, Gazzotti F, Pezzilli R, Nanetti A, Santini D, et al. Effect of early antibiotic prophylaxis with ertapenem and meropenem in experimental acute pancreatitis in rats. J Hepatobiliary Pancreat Surg (2009) 16:328-32. doi:10.1007/s00534-009-0047-0

26. Churg A, Richter WR. Early changes in the exocrine pancreas of the dog and rat after ligation of the pancreatic duct. A light and electron microscopic study. Am J Pathol (1971) 63:521-46.

27. National Research Council. Guide for the Care and Use of Laboratory Animals. Washington, DC: National Academies Press (2011).

28. Takeuchi O, Hoshino K, Kawai T, Sanjo H, Takada H, Ogawa T, et al. Differential roles of TLR2 and TLR4 in recognition of Gram-negative and Gram-positive bacterial cell wall components. Immunity (1999) 11:443-51. doi:10.1016/S1074-7613(00)80119-3

29. Reikvam DH, Erofeev A, Sandvik A, Grcic V, Jahnsen FL, Gaustad P, et al. Depletion of murine intestinal microbiota: effects on gut mucosa and epithelial gene expression. PLoS One (2011) 6:e17996. doi:10.1371/journal. pone.0017996

30. Alves-Filho JC, Freitas A, Souto FO, Spiller F, Paula-Neto H, Silva JS, et al. Regulation of chemokine receptor by toll-like receptor 2 is critical to neutrophil migration and resistance to polymicrobial sepsis. Proc Natl Acad Sci US A (2009) 106:4018-23. doi:10.1073/pnas.0900196106

31. Kaplan AH, Gilligan PH, Facklam RR. Recovery of resistant enterococci during vancomycin prophylaxis. J Clin Microbiol (1988) 26:1216-8.

32. Schwaiger K, Bauer J, Hormansdorfer S, Molle G, Preikschat P, Kampf P, et al. Presence of the resistance genes vanC1 and pbp5 in phenotypically vancomycin and ampicillin susceptible Enterococcus faecalis. Microb Drug Resist (2012) 18:434-9. doi:10.1089/mdr.2011.0227

33. Mestriner FL, Spiller F, Laure HJ, Souto FO, Tavares-Murta BM, Rosa JC, et al. Acute-phase protein alpha-1-acid glycoprotein mediates neutrophil migration failure in sepsis by a nitric oxide-dependent mechanism. Proc Natl Acad Sci US A (2007) 104:19595-600. doi:10.1073/pnas.0709681104

34. Spiller F, Carlos D, Souto FO, De Freitas A, Soares FS, Vieira SM, et al. alphal-Acid glycoprotein decreases neutrophil migration and increases susceptibility to sepsis in diabetic mice. Diabetes (2012) 61:1584-91. doi:10.2337/ db11-0825

35. Frossard JL, Steer ML, Pastor CM. Acute pancreatitis. Lancet (2008) 371:143-52. doi:10.1016/S0140-6736(08)60107-5

36. Oldfield EC III. Antibiotic prophylaxis in severe acute pancreatitis: the never-ending controversy. Rev Gastroenterol Disord (2005) 5:183-94.

37. Topham JC, Murgatroyd LB, Jones DV, Goonetilleke UR, Wright J. Safety evaluation of meropenem in animals: studies on the kidney. J Antimicrob Chemother (1989) 24(Suppl A):287-306. doi:10.1093/jac/24.suppl_A.287

38. Kohda A, Misaki Y, Hanai K, Inoue K, Kato T, Yamada H. [Acute toxicity study of meropenem in rats, mice and dogs]. Chemoteraphy (1992) 40:182-91.

39. Worthen GS, Schwab B III, Elson EL, Downey GP. Mechanics of stimulated neutrophils: cell stiffening induces retention in capillaries. Science (1989) 245:183-6. doi:10.1126/science. 2749255

40. Williams AE, Chambers RC. The mercurial nature of neutrophils: still an enigma in ARDS? Am J Physiol Lung Cell Mol Physiol (2014) 306:L217-30. doi:10.1152/ajplung.00311.2013

41. Schnoor M, Garcia Ponce A, Vadillo E, Pelayo R, Rossaint J, Zarbock A. Actin dynamics in the regulation of endothelial barrier functions and neutrophil recruitment during endotoxemia and sepsis. Cell Mol Life Sci (2017) 74: 1985-97. doi:10.1007/s00018-016-2449-x

42. Zhou MT, Chen CS, Chen BC, Zhang QY, Andersson R. Acute lung injury and ARDS in acute pancreatitis: mechanisms and potential intervention. World J Gastroenterol (2010) 16:2094-9. doi:10.3748/wjg.v16.i17.2094

43. Vincent S, Knight RG, Green M, Sahm DF, Shlaes DM. Vancomycin susceptibility and identification of motile enterococci. J Clin Microbiol (1991) 29:2335-7.

44. Van Den Bogert B, Meijerink M, Zoetendal EG, Wells JM, Kleerebezem M. Immunomodulatory properties of Streptococcus and Veillonella isolates from the human small intestine microbiota. PLoS One (2014) 9:e114277. doi:10.1371/journal.pone.0114277

45. Su KH, Cuthbertson C, Christophi C. Review of experimental animal models of acute pancreatitis. HPB (Oxford) (2006) 8:264-86. doi:10.1080/ 13651820500467358

46. Ayabe T, Satchell DP, Wilson CL, Parks WC, Selsted ME, Ouellette AJ. Secretion of microbicidal alpha-defensins by intestinal Paneth cells in response to bacteria. Nat Immunol (2000) 1:113-8. doi:10.1038/77783

47. Brandl K, Plitas G, Schnabl B, Dematteo RP, Pamer EG. MyD88-mediated signals induce the bactericidal lectin RegIII gamma and protect mice against intestinal Listeria monocytogenes infection. J Exp Med (2007) 204:1891-900. doi:10.1084/jem.20070563

48. Cash HL, Whitham CV, Behrendt CL, Hooper LV. Symbiotic bacteria direct expression of an intestinal bactericidal lectin. Science (2006) 313:1126-30. doi:10.1126/science.1127119

49. Yamanaka H, Takagi T, Ohsawa M, Yamamoto N, Kubo N, Takemoto T, et al. Identification and characterization of vancomycin-resistant Enterococcus species frequently isolated from laboratory mice. Exp Anim (2014) 63:297-304. doi:10.1538/expanim.63.297

50. Hoque R, Sohail M, Malik A, Sarwar S, Luo Y, Shah A, et al. TLR9 and the NLRP3 inflammasome link acinar cell death with inflammation in acute pancreatitis. Gastroenterology (2011) 141:358-69. doi:10.1053/j.gastro.2011.03.041

51. Sharif R, Dawra R, Wasiluk K, Phillips P, Dudeja V, Kurt-Jones E, et al. Impact of toll-like receptor 4 on the severity of acute pancreatitis and pancreatitis-associated lung injury in mice. Gut (2009) 58:813-9. doi:10.1136/ gut.2008.170423

52. Matsumura N, Takeyama Y, Ueda T, Yasuda T, Shinzeki M, Sawa H, et al. Decreased expression of toll-like receptor 2 and 4 on macrophages in experimental severe acute pancreatitis. Kobe J Med Sci (2007) 53:219-27.

53. Awla D, Abdulla A, Regner S, Thorlacius H. TLR4 but not TLR2 regulates inflammation and tissue damage in acute pancreatitis induced by retrograde infusion of taurocholate. Inflamm Res (2011) 60:1093-8. doi:10.1007/ s00011-011-0370-1

54. Pastor CM, Pugin J, Kwak B, Chanson M, Mach F, Hadengue A, et al. Role of toll-like receptor 4 on pancreatic and pulmonary injury in a mice model of acute pancreatitis associated with endotoxemia. Crit Care Med (2004) 32:1759-63. doi:10.1097/01.CCM.0000133020.47243.8E

55. Jung E, Byun S, Lee H, Moon SY, Lee H. Vancomycin-resistant Enterococcus colonization in the intensive care unit: clinical outcomes and attributable costs of hospitalization. Am J Infect Control (2014) 42:1062-6. doi:10.1016/j. ajic.2014.06.024

56. Antibiotic Resistance Threats in the United States. Center for Disease Control and Prevention, U.S. Department of Health and Human Services (2013).

57. Khan FY, Elshafi SS. Enterococcus gallinarum meningitis: a case report and literature review. J Infect Dev Ctries (2011) 5:231-4. doi:10.3855/jidc.1281

58. Narciso-Schiavon JL, Borgonovo A, Marques PC, Tonon D, Bansho ET, Maggi DC, et al. Enterococcus casseliflavus and Enterococcus gallinarum as causative agents of spontaneous bacterial peritonitis. Ann Hepatol (2015) 14:270-2.

59. Swampillai J, Liang M, Fisher R, Devlin G. Enterococcus gallinarum causing native valve endocarditis and aorto-atrial fistula: a case report and literature review. Echocardiography (2012) 29:873-5. doi:10.1111/j.1540-8175.2012.01685.x

60. Gibson MK, Wang B, Ahmadi S, Burnham CA, Tarr PI, Warner BB, et al. Developmental dynamics of the preterm infant gut microbiota and antibiotic resistome. Nat Microbiol (2016) 1:16024. doi:10.1038/nmicrobiol.2016.24

61. Capurso G, Zerboni G, Signoretti M, Valente R, Stigliano S, Piciucchi M, et al. Role of the gut barrier in acute pancreatitis. J Clin Gastroenterol (2012) 46(Suppl):S46-51. doi:10.1097/MCG.0b013e3182652096

62. Dickson RP, Erb-Downward JR, Prescott HC, Martinez FJ, Curtis JL, Lama VN, et al. Analysis of culture-dependent versus culture-independent 
techniques for identification of bacteria in clinically obtained bronchoalveolar lavage fluid. J Clin Microbiol (2014) 52:3605-13. doi:10.1128/JCM.01028-14

63. Abayasekara LM, Perera J, Chandrasekharan V, Gnanam VS, Udunuwara NA, Liyanage DS, et al. Detection of bacterial pathogens from clinical specimens using conventional microbial culture and 16S metagenomics: a comparative study. BMC Infect Dis (2017) 17:631. doi:10.1186/s12879-017-2727-8

64. Brandl K, Plitas G, Mihu CN, Ubeda C, Jia T, Fleisher M, et al. Vancomycinresistant enterococci exploit antibiotic-induced innate immune deficits. Nature (2008) 455:804-7. doi:10.1038/nature07250

65. Van Den Bogert B, Erkus O, Boekhorst J, De Goffau M, Smid EJ, Zoetendal EG, et al. Diversity of human small intestinal Streptococcus and Veillonella populations. FEMS Microbiol Ecol (2013) 85:376-88. doi:10.1111/1574-6941.12127

66. Tan C, Ling Z, Huang Y, Cao Y, Liu Q, Cai T, et al. Dysbiosis of intestinal microbiota associated with inflammation involved in the progression of acute pancreatitis. Pancreas (2015) 44:868-75. doi:10.1097/MPA.0000000000000355
67. Choi SH, Lee SO, Kim TH, Chung JW, Choo EJ, Kwak YG, et al. Clinical features and outcomes of bacteremia caused by Enterococcus casseliflavus and Enterococcus gallinarum: analysis of 56 cases. Clin Infect Dis (2004) 38: 53-61. doi:10.1086/380452

Conflict of Interest Statement: The authors declare that the research was conducted in the absence of any commercial or financial relationships that could be construed as a potential conflict of interest.

Copyright (c) 2017 Soares, Amaral, Silva, Valente, Santos, Yamashiro, Scheffer, Castanheira, Ferreira, Gehrke, Alves-Filho, Silva, Báfica and Spiller. This is an open-access article distributed under the terms of the Creative Commons Attribution License (CC BY). The use, distribution or reproduction in other forums is permitted, provided the original author(s) or licensor are credited and that the original publication in this journal is cited, in accordance with accepted academic practice. No use, distribution or reproduction is permitted which does not comply with these terms. 